\title{
Analisis Pengendalian Kualitas dalam Upaya Meminimalisasi Tingkat Kerusakan Produk Gula Rafinasi
}

\section{(Analysis of Quality Control in an Effort to Minimize the Breakdown Rate of Refined Sugar Products)}

\author{
Faris Ghiyats $^{1{ }^{1 *}}$, Fadila Marga Saty ${ }^{2)}$, Dewi Riniarti ${ }^{3)}$ \\ 1) Program Studi Produksi dan Manajemen Industri Perkebunan, Politeknik Negeri Lampung, \\ 2) Jurusan Ekonomi dan Bisnis, Politeknik Negeri Lampung, Jl. Soekarno-Hatta No. 10 Rajabasa, \\ Bandar Lampung, 35144, Telp.: (0721)703995, Fax.: (0721) 787309, 3) Jurusan Budidaya \\ Tanaman Perkebunan, Politeknik Negeri Lampung, Jl. Soekarno-Hatta No. 10 Rajabasa, Bandar \\ Lampung, 35144, Telp.: (0721) 703995, Fax.: (0721) 787309 \\ E-mail:vrisyats@gmail.com
}

\begin{abstract}
Non-conformance occurs due to unavoidable production process, and there is need to reduce the potential occurrences as well as provide a solution to minimize the level of mismatch. This study aims to identify the percentage and types of discrepancy experienced, by analyzing process capabilities and identify underlying factors in inconsistency. The research was performd in May 2018 at the department of process PT Sugar Labinta, Tanjung Sari, Lampung Selatan. Furthermore, analysis involved the six sigma method with a structured DMAIC approach, while the tools used include check sheet, caused diagram, p-control chart, and Pareto diagram. The results were then processed with the Minitab 18 software, which demonstrated the level sigma process in PT Sugar Labinta to be 5.04 with a DPMO of 238.32. The table of achievement indicates the company performance to be at an average level, in contrast with industries in the USA. However, the level of Sigma 6 is attainable under the circumstances where product-related inconsistences do not exceed 8 tonnes per month.
\end{abstract}

Keywords: quality control, refined sugar, six sigma

DOI: http://dx.doi.org/10.25181/jaip.v8i2.1319

Diterima: 30 Agustus 2019 / Disetujui: 1 Agustus 2020 / Diterbitkan: 5 Oktober 2020

\section{PENDAHULUAN}

Kebutuhan gula nasional pada lima tahun terakhir mencapai sekitar 6 juta ton, jauh dari produksi dalam negeri yang berkisar 2,5 juta ton (Saputra, 2020; Basuki \& Sari, 2020). Konsumsi ini terdiri dari perkebunan gula putih (GKP) untuk konsumsi rumah tangga langsung sebesar 51\% dan gula rafinasi (GKR) untuk kebutuhan industri makanan dan minuman sebesar $47 \%$ dan konsumsi lainnya sebesar 2\% sehingga masih diperlukan impor sebanyak 3,5 juta ton (Pusat Pengkajian Perdagangan dalam Negeri, 2018). Fajrin, Hartono, \& Waluyati (2015) menjelaskan bahwa gula rafinasi merupakan gula industri yang diproduksi menggunakan raw sugar (gula mentah) sebagai bahan baku utama dan lebih dipilih oleh industri makanan, minuman, maupun farmasi sebagai bahan baku industrinya jika dibandingkan dengan GKP karena tingkat kemurnian 
yang dimiliki gula rafinasi juga lebih tinggi, butiran kristal lebih halus, serta warna yang lebih putih. Gula rafinasi diproduksi sesuai dengan speksifikasi yang disesuaikan dengan permintaan masing-masing industri tidak terlepas oleh adanya defect. Bustami \& Nurlela (2007) mendefinisikan produk cacat dihasilkan dari suatu proses produksi akibat ketidaksesuaian dengan standar mutu yang ditetapkan dan dapat diperbaiki dengan mengeluarkan biaya tertentu. Oleh karena itu, perusahaan perlu pengendalian kualitas secara berkelanjutan sebagai acuan untuk meminimalisasi terjadinya kerugian akibat remelt (proses ulang) dari adanya ketidaksesuaian speksifikasi.

Metode produksi gula rafinasi pada PT Sugar Labinta mengacu pada Standar Nasional Indonesia (SNI) 3140.2:2011 Gula kristal - Bagian 2: Rafinasi (Refined Sugar) dan telah menerapkan Sistem Manajemen Mutu dan Keamanan Pangan sesuai Pedoman ISO 9001: 2008, FSSC 22000: 2010 (Food Safety System Certification yang merupakan gabungan dari ISO 22000: 2005 dan PAS 220: 2008 / ISO TS: 22002-1), Sistem Jaminan Halal, SMETA (Sedex Members Ethical Trade Audit) serta pemenuhan dari setiap persyaratan standar mass balance COC BONSUCRO, pada seluruh aktivitas proses. Gula rafinasi R1 yang diproduksi oleh PT Sugar Labinta merupakan produk utama dengan speksifikasi kualitas terbaik. Namun, penyimpangan proses produksi yang terjadi akan berdampak terhadap penurunan kuantitas maupun kualitas (downgrade) sehingga dapat diklasifikasikan menjadi beberapa produk turunan seperti gula R2, C1, C2, C3, dan C4. Permasalahan tersebut dikendalikan agar jumlah produk turunan yang diproduksi dapat diminimalisasi semaksimal mungkin oleh perusahaan. Six sigma bertujuan untuk menemukan dan mengurangi faktor-faktor penyebab kecacatan dan kesalahan, mengurangi waktu siklus dan biaya operasi, meningkatkan produktivitas dan memenuhi kebutuhan pelanggan dengan lebih baik (Assauri, 2016). Penelitian ini bertujuan untuk mengidentifikasi persentase dan jenis defect yang dialami perusahaan, menganalisis kapabilitas proses, serta mengidentifikasi faktor penyebab timbulnya defect di PT Sugar Labinta.

\section{METODE PENELITIAN}

Pelaksanaan penelitian dilaksanakan pada bulan Mei 2018 di PT Sugar Labinta, Tanjung Sari, Lampung Selatan. Analisis data yang dilakukan pada penelitian ini menggunakan pendekatan DMAIC atau Define, Measure, Analyze, Improve dan Control (Ekoanindiyo, 2014; Findari \& Nugroho, 2019) yang merupakan proses peningkatan terus-menerus menuju target six sigma dan dilanjutkan mengukur kapabilitas proses $(\mathrm{Cp})$. Define adalah mengidentifikasi masalah penting dalam proses yang sedang berlangsung. Alat yang digunakan adalah diagram SIPOC dan critical to quality (CTQ). Measure adalah tahap untuk memvalidasi permasalahan, mengukur atau menganalisis permasalahan dari data yang ada.pada tahap ini dapat diketahui posisi perusahaan 
dalam tingkatan sigma. Alat yang digunakan adalah $\mathrm{P}$ chart melalui bantuan software minitab 18, tingkat sigma dan kapabilitas proses dilakukan melalui tahapan berikut ini:

\section{1) Analisis tingkat sigma}

Menganalisis tingkat sigma dan Defect Per Milion Opportunitas (DPMO) perusahaan adalah sebagai berikut:

1. Defect Per Unit (DPU)

$$
D P U=\frac{D}{U}
$$

Keterangan:

DPU : Defect Per Unit (kerusakan setiap satuan)

D : Defect (kerusakan)

U : Unit (satuan)

2. Total Opportunities (TOP)

$$
T O P=U \times O P
$$

Keterangan:

TOP $\quad$ :Total Opportunities (total peluang)

U : Unit (satuan)

OP : Opportunities (peluang)

3. Defect Per Opportunities (DPO)

$$
D P O=\frac{D}{T O P}
$$

Keterangan:

DPO : Defect Per Opportunities (kerusakan setiap peluang)

D : Defect (kerusakan)

TOP : Total Opportunities (total peluang)

4. Defect Per Million Opportunities (DPMO)

$$
D P M O=D P O \times 1000000
$$

Keterangan:

DPMO : Defect Per Million Opportunities

DPO : Defect Per Opportunities

5. Tingkat Sigma

Menggunakan software Ms.Excel, nilai pencapaian sigma dapat diketahui dengan rumus (Evans \& Lindsay, 2007):

$$
\text { Level Sigma }=\text { Normsinv }\left(\frac{1000000-\text { DPMO }}{1000000}\right)+1,5
$$

\section{2) Analisis kapabilitas proses}

Perhitungan dilakukan dengan mensubstitusikan nilai DPMO sebesar 3,4 pada rumus DPMO (Prawira, 2014), hal ini dimaksudkan untuk mencapai 6 sigma perlu menentukan batas toleransi jumlah defect per bulan: 


$$
\mathrm{DPMO}=\frac{\text { Total Defect }}{\text { Total Opportunity }} \times 1.000 .000
$$

Kapabilitas proses (Cp) dihitung menggunakan rumus(Park, 2003; Sulistyowati \& Anggarini, 2017):

$$
C P=\frac{\text { Level Sigma }}{3}
$$

Analyze adalah menentukan faktor-faktor yang paling mempengaruhi proses. Alat yang digunakan adalah diagram pareto dan diagram sebab akibat. Improve adalah melakukan percobaan untuk melihat hasilnya, jika bagus lalu dibuatkan prosedur bakunya. Alat yang digunakan adalah FMEA (Failure Mode and Effect Analysis) melalui perhitungan nilai Risk Priority Number (RPN) untuk menentukan prioritas masalah menggunakan rumus sebagai berikut:

$$
R P N=S \times O \times D
$$

Keterangan:

$\begin{array}{ll}\text { RPN } & \text { : Risk Priority Number } \\ \text { S } & : \text { Severity } \\ \text { O } & : \text { Occurance } \\ \text { D } & : \text { Detection }\end{array}$

Bahan yang digunakan adalah data primer berupa informasi proses produksi dan data sekunder berupa data jumlah produksi dan jumlah ketidaksesuaian pada produk gula rafinasi selama bulan Januari 2017-Agustus 2018. Metode pengumpulan data yang digunakan dalam penelitian ini adalah dengan melakukan pengamatan langsung, data sekunder, dan wawancara di perusahaan yang menjadi objek penelitian. Variabel yang diamati melalui pengujian laboratorium adalah variabel yang mengalami ketidaksesuaian spesifikasi berdasarkan permintaan konsumen dan acuan SNI seperti moist (susut pengeringan) dan color (warna) sedangkan untuk pengamatan secara fisik, variabel yang diamati seperti banyaknya jahitan lepas dan kemasan sobek.

\section{HASIL DAN PEMBAHASAN}

\section{Analisis Pengendalian Kualitas Gula Rafinasi}

\section{Tahap define}

Define merupakan tahap pra analisis data dalam metode six sigma yang bertujuan untuk menetapkan titik pengamatan proses, dan menjelaskan permasalahan berkaitan dengan defect. Proses produksi gula rafinasi dimulai dari pelunakan, sentrifugasi, peleburan, karbonatasi, filtrasi, dekolorisasi, evaporasi, pemasakan, sentrifugasi, pengeringan, pengemasan, dan penyimpanan. Evaporasi, sentrifugasi, dan pengeringan merupakan proses yang dipilih untuk mengamati kriteria dengan jenis defect moist (susut pengeringan) kemudian pada kriteria defect color (warna) yang diamati adalah proses affinasi, karbonatasi serta dekolorisasi sedangkan proses yang dipilih untuk defect kemasan ialah dengan mengamati proses pengepakan, penyimpanan maupun saat 
pengangkutan barang. Terdapat tiga jenis kriteria ketidaksesuaian pada produk yang dijadikan sebagai critical to quality (CTQ), yaitu: kerapatan kemasan (kemasan sobek dan jahitan lepas), daya tahan produk (susut pengeringan), dan kemurnian gula (warna).

\section{Tahap measure}

Tahap ini merupakan tahap awal analisis data dalam pengendalian kualitas pada metode six sigma. Pembuatan check sheet diperlukan dalam proses pengumpulan data serta analisis untuk mengetahui lingkup permasalahan berdasarkan frekuensi dari jenis ketidaksesuaian yang ada. Jumlah produk yang dihasilkan oleh PT Sugar Labinta tiap bulannya mengalami fluktuasi. Hal tersebut dikarenakan banyaknya produk yang dihasilkan menyesuaikan dengan permintaan konsumen dan kemampuan unit produksi. Unit produksi yang terkendali tentunya akan menghasilkan suatu produk dengan kualitas dan jumlah yang maksimal (Gula MR/R1). Tabel 1 menampilkan banyaknya jumlah ketidaksesuaian terhadap jumlah produk jadi yang telah dikonversikan ke satuan ton.

Tabel 1. Jumlah produksi dan jumlah defect gula rafinasi Januari 2017 sampai Agustus 2018

\begin{tabular}{|c|c|c|c|c|c|c|c|c|c|}
\hline \multirow[b]{2}{*}{ Bulan } & \multirow[b]{2}{*}{ Produksi } & \multirow[b]{2}{*}{ Hari } & \multirow[b]{2}{*}{$\begin{array}{l}\text { Produk } \\
\text { Jadi } \\
\text { (ton) }\end{array}$} & \multicolumn{4}{|c|}{ Jenis Defect } & \multirow[b]{2}{*}{$\begin{array}{l}\text { Total } \\
\text { (ton) }\end{array}$} & \multirow[b]{2}{*}{$\begin{array}{c}\text { Defect } \\
(\%)\end{array}$} \\
\hline & & & & $\begin{array}{l}\text { Susut } \\
\text { pengeringan } \\
\text { (ton) }\end{array}$ & $\begin{array}{l}\text { Warna } \\
\text { (ton) }\end{array}$ & $\begin{array}{l}\text { Jahita } \\
\mathrm{n} \\
\text { Lepas } \\
\text { (ton) }\end{array}$ & $\begin{array}{c}\text { Kemasan } \\
\text { Sobek } \\
\text { (ton) }\end{array}$ & & \\
\hline Januari 2017 & 45.353 & 31 & 43.539 & 6 & 4 & 3 & 3 & 16 & 0,04 \\
\hline Februari 2017 & 41.076 & 28 & 39.433 & 4 & 8 & 4 & 2 & 18 & 0,05 \\
\hline Maret 2017 & 42.780 & 31 & 41.069 & 4 & 12 & 3 & 4 & 23 & 0,06 \\
\hline April 2017 & 47.100 & 30 & 45.216 & 8 & 5 & 1 & 6 & 20 & 0,04 \\
\hline Mei 2017 & 51.398 & 31 & 49.342 & 40 & 60 & 3 & 5 & 108 & 0,22 \\
\hline Juni 2017 & 6.164 & 4 & 5.917 & 2 & 0 & 6 & 3 & 11 & 0,19 \\
\hline Juli 2017 & 47.027 & 31 & 45.146 & 6 & 3 & 15 & 16 & 40 & 0,09 \\
\hline Agustus 2017 & 49.538 & 31 & 47.557 & 5 & 10 & 11 & 13 & 39 & 0,08 \\
\hline September 2017 & 46.380 & 30 & 44.525 & 9 & 4 & 5 & 6 & 24 & 0,05 \\
\hline Oktober 2017 & 49.197 & 31 & 47.229 & 14 & 7 & 4 & 6 & 31 & 0,07 \\
\hline November 2017 & 44.370 & 30 & 42.595 & 4 & 5 & 3 & 7 & 19 & 0,04 \\
\hline Desember 2017 & 41.850 & 31 & 40.176 & 8 & 3 & 7 & 4 & 22 & 0,05 \\
\hline Januari 2018 & 40.176 & 31 & 35.998 & 5 & 14 & 2 & 2 & 23 & 0,06 \\
\hline Februari 2018 & 38.640 & 28 & 29.637 & 7 & 2 & 3 & 3 & 15 & 0,05 \\
\hline Maret 2018 & 49.405 & 31 & 36.362 & 10 & 8 & 0 & 4 & 22 & 0,06 \\
\hline April 2018 & 50.520 & 30 & 43.599 & 3 & 1 & 1 & 5 & 10 & 0,02 \\
\hline Mei 2018 & 52.948 & 31 & 47.124 & 9 & 6 & 27 & 24 & 66 & 0,14 \\
\hline Juni 2018 & 6.084 & 4 & 4.806 & 0 & 0 & 0 & 1 & 1 & 0,02 \\
\hline Juli 2018 & 49.817 & 31 & 39.405 & 5 & 2 & 7 & 7 & 21 & 0,05 \\
\hline Agustus 2018 & 47.771 & 31 & 39.125 & 2 & 7 & 2 & 5 & 16 & 0,04 \\
\hline Total & 847.594 & 339 & 767.800 & 151 & 161 & 107 & 126 & 545 & \\
\hline Rata-rata & 42.380 & 17 & 38.390 & 8 & 8 & 5,35 & 6,3 & 27,25 & 0,07 \\
\hline
\end{tabular}


Berdasarkan Tabel 1 diketahui tingkat defect terendah terdapat pada bulan Juni 2018 yaitu sebesar $0,02 \%$ dengan produk yang dihasilkan sejumlah 4.806 ton, sedangkan persentase defect sebesar 0,22\% pada bulan Mei 2017 merupakan tingkat defect tertinggi dengan jumlah produk jadi 49.342 ton. Produk yang dihasilkan tiap bulan Juni lebih rendah dibandingkan dengan bulan lainnya, hal ini disebabkan karena pada bulan tersebut perusahaan melakukan maintenance total. Perusahaan menetapkan target tingkat defect sebesar $0,03 \%$ namun melalui pengamatan data sekunder selama 20 bulan diketahui bahwa rata-rata tingkat defect yang terjadi tiap bulan masih berada di $0,07 \%$ sehingga belum mencapai target. Berikut merupakan perhitungan control $\mathrm{P}$ chart yang ditampilkan dalam Gambar 1.

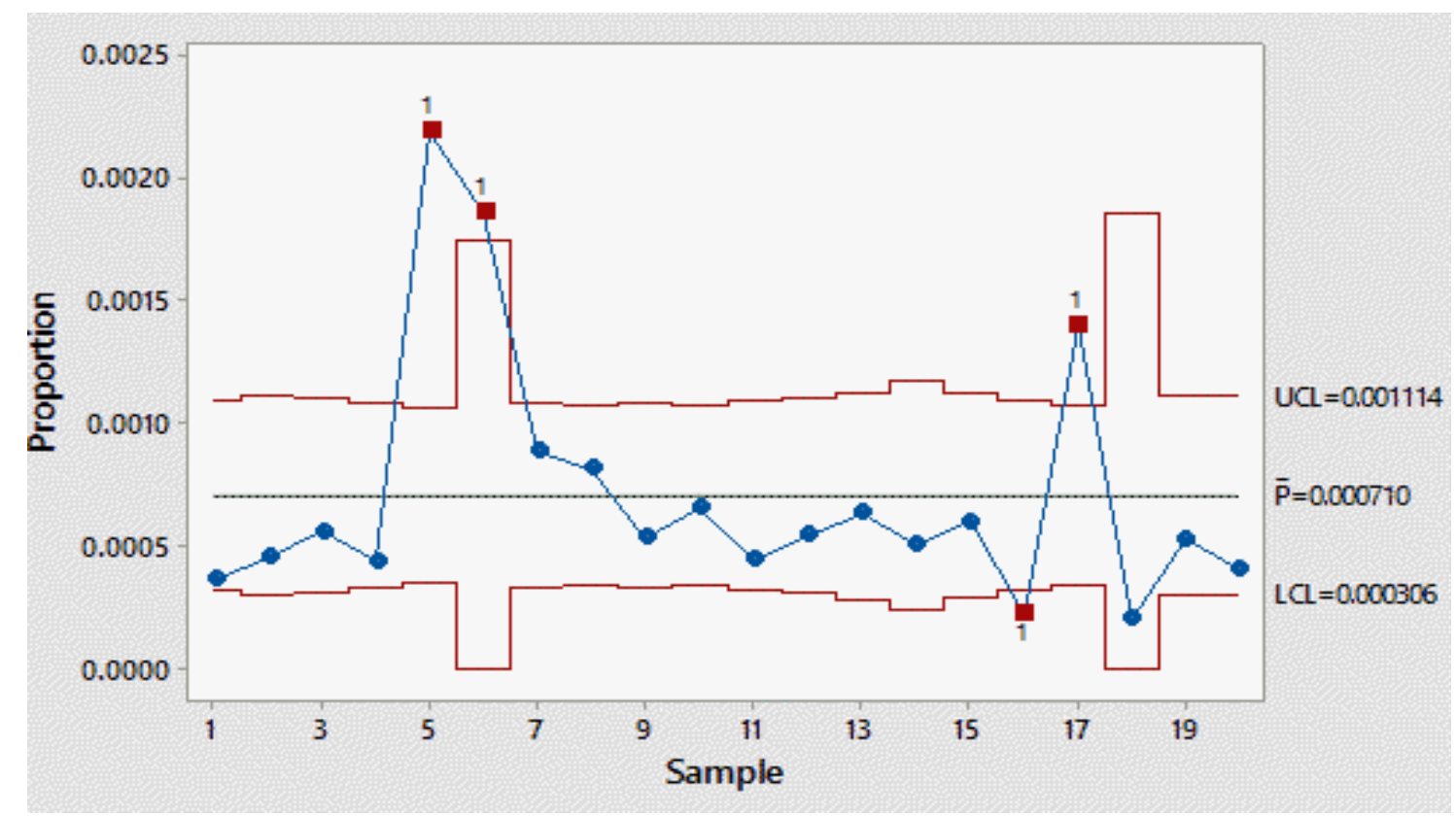

Gambar 1. P-Chart defect produk gula rafinasi sebelum perbaikan

Gambar 1 menunjukan kondisi data dalam bentuk grafik sebelum dilakukan perbaikan terlihat bahwa terdapat empat titik yang berada diluar batas kendali diantaranya tiga titik berada diluar Upper Control Limit (UCL) yaitu pada bulan April 2017, Mei 2017, Mei 2018 dan dan satu titik berada di luar Lower Control Limit (LCL) pada bulan April 2018. Data ke 16 yang terletak di bulan April 2018 berada diluar LCL menunjukan bahwa perusahaan mampu meminimalisir jumlah defect dengan maksimal. Peta kendali tersebut memperlihatkan nilai CL sebesar 0,000710, UCL sebesar 0,001114, dan LCL sebesar 0,000306. Tindakan revisi atau penghilangan data sebagai akibat adanya penyimpangan yang terindentifikasi data ekstrim dilakukan untuk menyeragamkan data sebelum dilakukannya penghitungan tingkat sigma. 


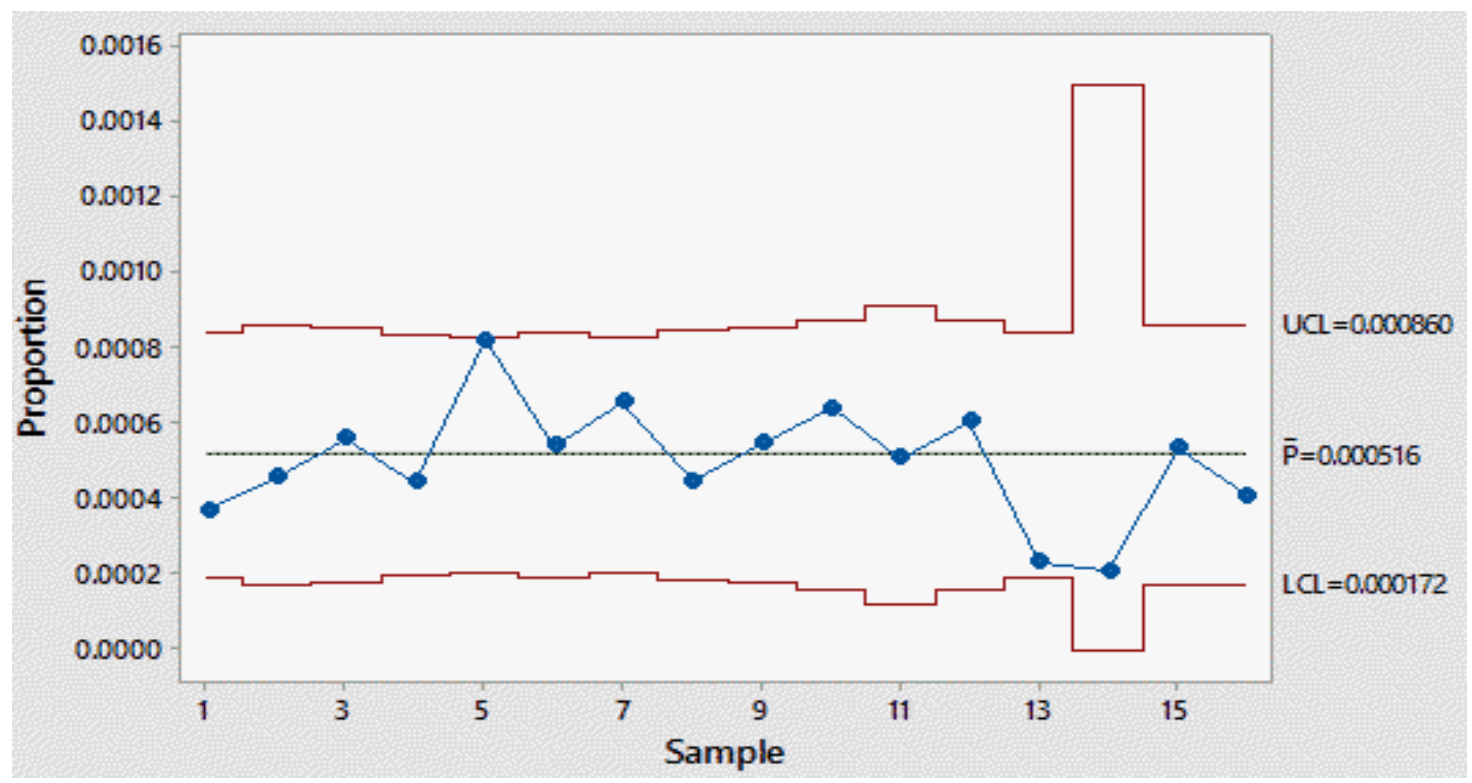

Gambar 2. P-Chart defect produk gula rafinasi sesudah perbaikan

Gambar 2 memperlihatkan keseluruhan data telah berada didalam batas control UCL maupun LCL setelah melakukan revisi sebanyak empat kali kemudian dilanjutkan menghitung nilai DPMO yang akan menunjukan level sigma pada proses produksi gula rafinasi. Hasil nilai sigma pada tiap bulannya ditampilkan pada Tabel 2 berikut ini:

Tabel 2. Tingkat sigma

\begin{tabular}{clrrrrrr}
\hline $\begin{array}{c}\text { Data } \\
\text { ke }\end{array}$ & \multicolumn{1}{c}{ Bulan } & $\begin{array}{c}\text { Produk } \\
\text { Jadi (ton) }\end{array}$ & $\begin{array}{c}\text { Total Defect } \\
\text { (ton) }\end{array}$ & CTQ & DPO & DPMO & Nilai Sigma \\
\hline 1 & Januari 2017 & 43.539 & 16 & 3 & 0,0001225 & 122,50 & 5,17 \\
2 & Februari 2017 & 39.433 & 18 & 3 & 0,0001522 & 152,16 & 5,11 \\
3 & Maret 2017 & 41.069 & 23 & 3 & 0,0001867 & 186,68 & 5,06 \\
4 & April 2017 & 45.216 & 20 & 3 & 0,0001474 & 147,44 & 5,12 \\
5 & Mei 2017 & 49.342 & 108 & 3 & 0,0007296 & 729,60 & 4,68 \\
6 & Juni 2017 & 5.917 & 11 & 3 & 0,0006197 & 619,68 & 4,73 \\
7 & Juli 2017 & 45.146 & 40 & 3 & 0,0002953 & 295,34 & 4,94 \\
8 & Agustus 2017 & 47.557 & 39 & 3 & 0,0002734 & 273,36 & 4,96 \\
9 & September 2017 & 44.525 & 24 & 3 & 0,0001797 & 179,67 & 5,07 \\
10 & Oktober 2017 & 47.229 & 31 & 3 & 0,0002188 & 218,79 & 5,02 \\
11 & November 2017 & 42.595 & 19 & 3 & 0,0001487 & $148, .69$ & 5,12 \\
12 & Desember 2017 & 40.176 & 22 & 3 & 0,0001825 & 182,53 & 5,06 \\
13 & Januari 2018 & 35.998 & 23 & 3 & 0,0002130 & 212,97 & 5,02 \\
14 & Februari 2018 & 29.637 & 15 & 3 & 0,0001687 & 168,71 & 5,08 \\
15 & Maret 2018 & 36.362 & 22 & 3 & 0,0002017 & 201,68 & 5,04 \\
16 & April 2018 & 43.599 & 10 & 3 & 0,0000765 & 76,45 & 5,29 \\
17 & Mei 2018 & 47.124 & 66 & 3 & 0,0004669 & 466,85 & 4,81 \\
18 & Juni 2018 & $4 . .806$ & 1 & 3 & 0,0000694 & 69,36 & 5,31 \\
19 & Juli 2018 & 39.405 & 21 & 3 & 0,0001776 & 177,64 & 5,07 \\
20 & Agustus 2018 & 39.125 & 16 & 3 & 0,0001363 & 136,32 & 5,14 \\
\hline
\end{tabular}


Nilai rata-rata DPMO pada bulan Januari 2017 sampai dengan Agustus 2018 adalah 238,32 dapat disimpulkan bahwa dari sejuta produk yang ada akan terdapat 238,32 ton kemungkinan defect. Perusahaan mencapai nilai sigma tertinggi di bulan April 2018 yaitu 5,29 dan nilai sigma terendah terdapat pada bulan Mei 2017 dengan nilai sigma sebesar 4,68.

Tabel 3. Tingkat pencapaian sigma

\begin{tabular}{cccl}
\hline $\begin{array}{c}\text { Persentase yang Memenuhi } \\
\text { Spesifikasi (\%) }\end{array}$ & $\begin{array}{c}\text { DPMO (defect per } \\
\text { million opportunity) }\end{array}$ & $\begin{array}{c}\text { Level } \\
\text { Sigma }\end{array}$ & \multicolumn{1}{c}{ Keterangan } \\
\hline 31 & $691.426,0$ & 1 & Sangat tidak kompetitif \\
69,20 & $308.538,0$ & 2 & Rata-rata industri Indonesia \\
93,32 & $66.807,0$ & 3 & Rata-rata industri Indonesia \\
99,379 & $6.210,0$ & 4 & Rata-rata industri USA \\
99,977 & 233,0 & 5 & Rata-rata industri USA \\
99,9997 & 3,4 & 6 & Industri kelas dunia \\
\hline
\end{tabular}

Berdasarkan acuan pencapaian sigma pada Tabel 3 maka proses produksi di PT Sugar Labinta dengan nilai sigma rata-rata 5,04 dapat dikatagorikan masuk ke dalam tingkatan kualitas rata-rata industri USA. Namun, perusahaan perlu melakukan pengendalian kualitas secara berkelanjutan untuk mencapai tingkat 6 sigma yaitu dengan menetapkan target defect. Perhitungan dilakukan dengan mensubstitusikan nilai DPMO sebesar 3,4 pada rumus DPMO (Prawira, 2014):

$$
\begin{gathered}
\text { DPMO }=\frac{\text { Total } \text { Defect }}{\text { Total } \text { Opportunity }} \times 1.000 .000 \\
3,4=\frac{\text { Total } \text { Defect }}{767.800 \times 3} \quad \times 1.000 .000 \\
7.831 .560 \quad=\text { Total Defect } \times 1.000 .000
\end{gathered}
$$

Total Defect $\quad=7,8316$ ton $\approx 8$ ton

Level sigma enam $(6 \sigma)$ dapat tercapai apabila jumlah defect yang dihasilkan akibat proses tidak melebihi 8 ton per bulannya sehingga PT Sugar Labinta mampu menjadi industri kelas dunia. Tahapan selanjutnya melakukan perhitungan indeks kapabilitas proses (Cp) selama bulan Januari 2017 sampai dengan Agustus 2018 dihitung menggunakan rumus (Park, 2003; Sulistyowati \& Anggarini, 2017):

$$
\begin{aligned}
\mathrm{Cp} & =\frac{\text { Level Sigma }}{3} \\
& =\frac{5,09}{3} \\
& =1,696 \approx 1,67
\end{aligned}
$$

Hasil perhitungan kapabilitas proses untuk data atribut menunjukkan nilai $\mathrm{Cp}=1,67$ sehingga dapat dikatakan bahwa kapabilitas proses terbilang sangat baik karena $\mathrm{Cp}>1,33$ sesuai dengan Tabel 4. 
Tabel 4. Kondisi suatu proses (Cp)

\begin{tabular}{cl}
\hline $\mathrm{Cp}$ (kapabilitas Proses) & \multicolumn{1}{c}{ Keterangan } \\
\hline $\mathrm{Cp}>1,33$ & Kapabilitas proses sangat baik. \\
$1,00 \leq \mathrm{Cp} \leq 1,33$ & $\begin{array}{l}\text { Kapabilitas proses baik, namun perlu pengendalian ketat apabila } \mathrm{Cp} \\
\text { mendekati 1,00. } \\
\mathrm{Cp}<1,00\end{array}$ \\
$\begin{array}{l}\text { Kapabilitas proses rendah, sehingga perlu ditingkatkan performansinya } \\
\text { melalui perbaikan proses itu. }\end{array}$ \\
\hline
\end{tabular}

Sumber: Wiyono (2004)

Perhitungan indeks kapabilitas proses (Cpk) diperoleh dari hasil interpolasi konversi level sigma dengan mengacu pada nilai sigma yang berada pada level 5,09 sigma. Nilai Cpk diketahui melalui perhitungan berikut ini (Febrina, 2007):

$$
\begin{aligned}
\text { Cpk } & =\frac{5,09-5}{6-5}=\frac{x-1,167}{1,5-1,167} \\
& =\frac{0,09}{1}=\frac{x-1,167}{0,333} \\
x & =(0,09 \times 0,3-33)+1,167 \\
x & =1,198
\end{aligned}
$$

Penelitian terdahulu Arum (2017) menjelaskan indeks kapabilitas proses yang diperoleh PT Tjoekir Jombang secara berturut-turut 1,1 dan 1,39. Hasil indeks kapabilitas proses di PT Sugar Labinta memiliki kesamaan dengan perusahaan gula PT Tjoekir Jombang yaitu nilai Cpk sebesar 1,198 sehingga dapat disimpulkan bahwa kemampuan proses tiap parameter seperti warna, susut pengeringan dan pengemasan cukup mampu menghasilkan produk sesuai speksifikasi karena Cpk $<$ 1,5 maka perlu upaya-upaya giat untuk peningkatan kualitas menuju target yang diinginkan sesuai acuan pada Tabel 5.

Tabel 5. Kondisi suatu proses (Cpk)

\begin{tabular}{cl}
\hline $\begin{array}{c}\text { Cpk (indeks kapabilitas } \\
\text { proses) }\end{array}$ & \multicolumn{1}{c}{ Keterangan } \\
\hline $\mathrm{Cpk} \geq 1,5$ & $\begin{array}{l}\text { Proses dianggap mampu dan kompetitif. } \\
\text { maka proses dianggap cukup mampu, namun perlu upaya-upaya giat untuk } \\
\text { peningkatan kualitas menuju target yang diinginkan. Perusahaan yang } \\
\text { berada di level ini memiliki kesempatan terbaik dalam melakukan program } \\
\text { peningkatan kualitas six sigma. } \\
\text { maka proses dianggap tidak mampu dan tidak kompetitif untuk bersaing di } \\
\text { pasar global. }\end{array}$ \\
\hline
\end{tabular}

Sumber: (Liquiddanu, 2007) 


\section{Tahap analyze}

Tahap yang dilakukan untuk mengidentifikasi faktor- faktor yang mempengaruhi dan faktor yang dianggap paling dominan agar dapat dilakukan perbaikan terhadap proses.

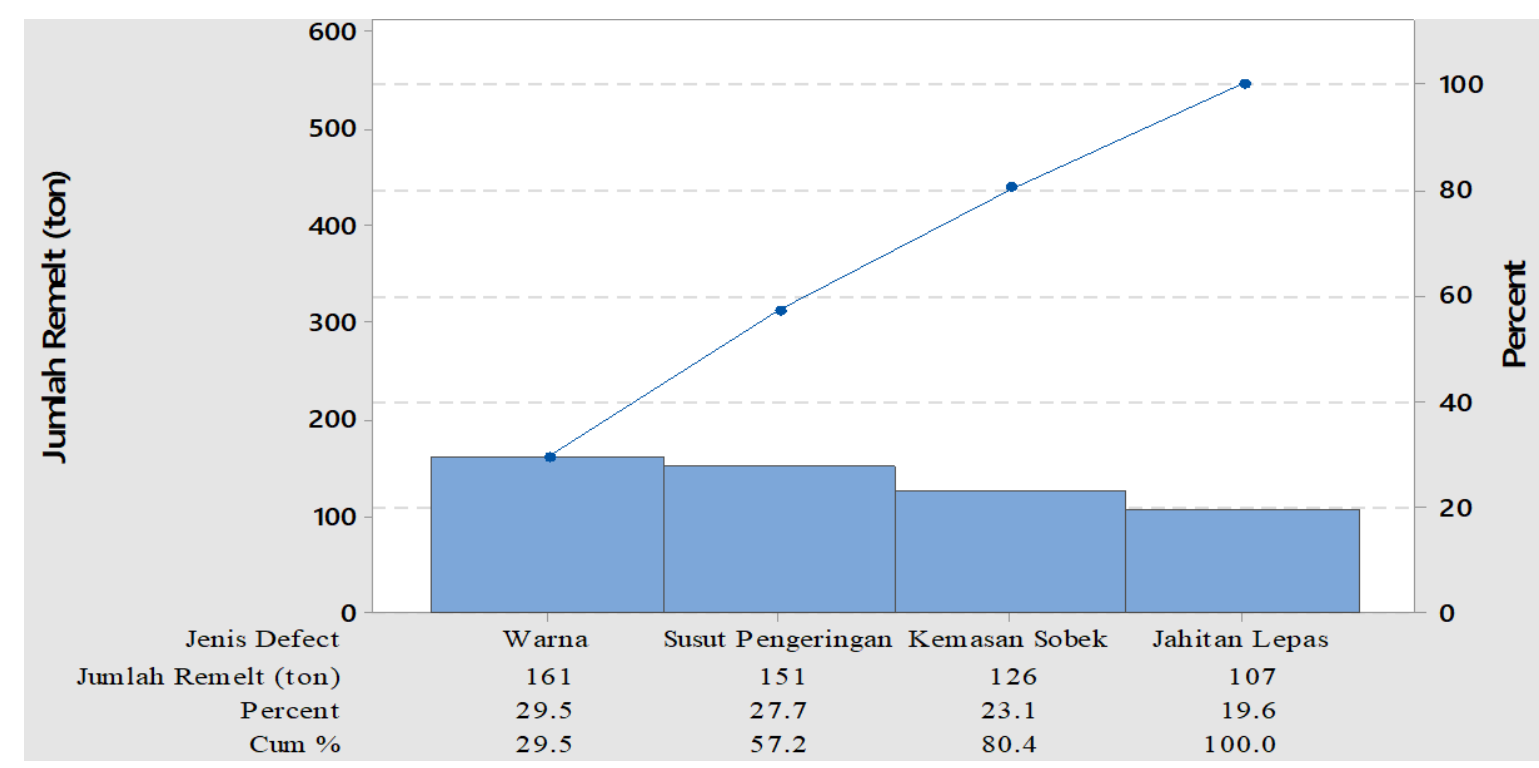

Gambar 3 Diagram Pareto jumlah remelt dari masing-masing jenis defect

Berdasarkan Gambar 2, jenis defect dominan yang diamati melalui analisis kimia adalah kriteria warna $(29,5 \%)$ dan susut pengeringan $(27,7 \%)$ sedangkan fisik yaitu kemasan sobek $(23,1 \%)$ dan jahitan lepas $(19,16 \%)$, sehingga jenis defect yang berkontribusi besar memberikan kerugian secara kimia dan fisika adalah warna dan kemasan sobek. Berikut ini merupakan analisis menggunakan diagram sebab akibat

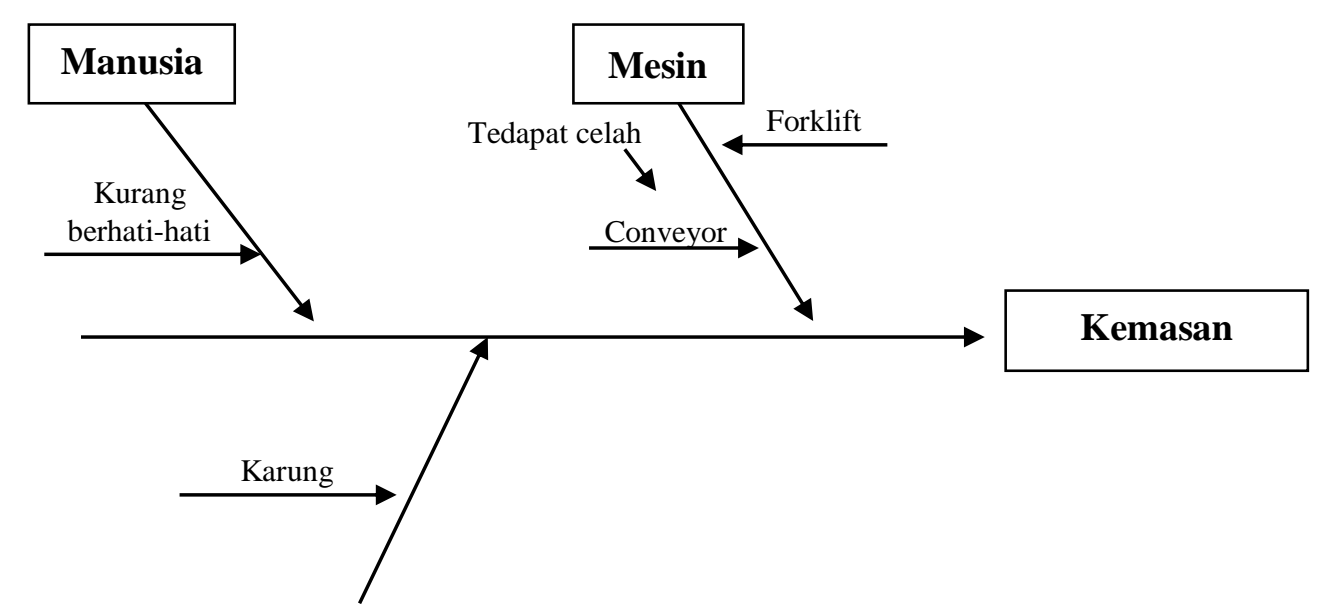

\section{Material}

Gambar 4. Diagram sebab-akibat kemasan sobek 


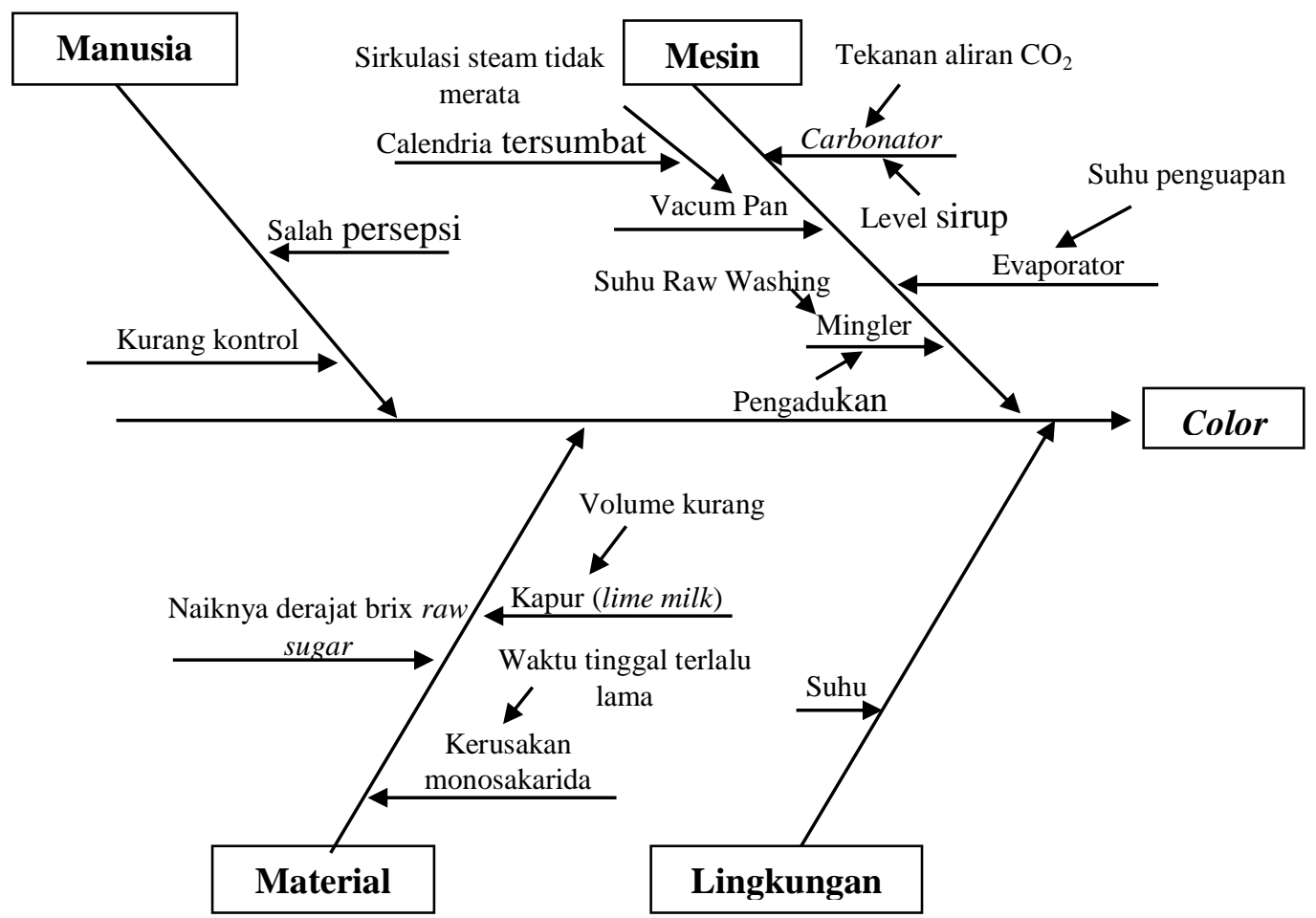

Gambar 5. Diagram sebab-akibat colour (Warna)

\section{Tahap improve}

Pada tahap ini, akar permasalahan yang telah diuraikan dengan menggunakan diagram tulang ikan, akan dianalisis dengan cara mengidentifikasi modus kegagalan, efek dan sebab modus kegagalan serta dihitung prioritas penyelesaian masalah melalui hasil nilai Risk Priority Number (RPN). Nilai tersebut ditentukan melalui tabel acuan severity (tingkat keparahan), occurity (tingkat kejadian), detectability (tingkat deteksi) pada Tabel 5,6, dan 7.

Tabel 6. Rating severity (tingkat keparahan)

\begin{tabular}{cl}
\hline Rangking & \multicolumn{1}{c}{ Kriteria } \\
\hline 1 & $\begin{array}{l}\text { Negilible Severity (pengaruh buruk yang dapat diabaikan). } \\
\text { Pengguna akhir mungkin tidak akan memperhatikan kecacatan ini. }\end{array}$ \\
\hline $2-3$ & $\begin{array}{l}\text { Mild Severity (pengaruh buruk yang ringan). Akibat yang ditimbulkan hanya bersifat ringan. } \\
\text { Pengguna akhir tidak akan merasakan perubahan kinerja. }\end{array}$ \\
\hline 4-6 & $\begin{array}{l}\text { Moderate Severity (pengaruh buruk yang moderat). Pengguna akhir akan merasakan penurunan } \\
\text { kinerja, namun masih dalam batas toleransi. Perbaikan yang dilakukan tidak memakan biaya } \\
\text { besar dan dapat diselesaikan dalam waktu singkat. }\end{array}$ \\
\hline $7-8$ & $\begin{array}{l}\text { High Severity (pengaruh buruk yang tinggi). Pengguna akhir akan merasakan akibat buruk yang } \\
\text { tidak akan diterima, berada diluar batas toleransi. Perbaikan yang dilakukan sangat mahal. }\end{array}$ \\
\hline $9-10$ & $\begin{array}{l}\text { Potential Safety Problem (masalah keamanan potensial). Akibat yang ditimbulkan berpengaruh } \\
\text { terhadap keselamatan pengguna. Bertentangan dengan hukum. }\end{array}$ \\
\hline
\end{tabular}

Sumber: Gasperz (2002) 
Tabel 7. Rating occurance (tingkat kejadian)

\begin{tabular}{crc}
\hline Rating & Frekuensi kejadian & Degree \\
\hline 1 & 0,01 per 1000 item & Remote \\
\hline 2 & 0,10 per 1000 item & Low \\
3 & 0,50 per 1000 item & \multirow{2}{*}{ Moderate } \\
5 & 1,00 per 1000 item & \multirow{2}{*}{ High } \\
6 & 2,00 per 1000 item & \multirow{2}{*}{ Very High } \\
\hline 7 & 5,00 per 1000 item & \\
\hline 9 & 10,00 per 1000 item & \\
\hline
\end{tabular}

Sumber: Gasperz (2002).

Tabel 8. Rating detectibility (tingkat deteksi)

\begin{tabular}{|c|c|c|}
\hline Rangking & Kriteria & Frekuensi \\
\hline 1 & $\begin{array}{l}\text { Metode pencegahan sangat efektif. Tidak ada kesempatan } \\
\text { bahwa penyebab mungkin muncul }\end{array}$ & 0,01 per 1000 item \\
\hline $2-3$ & Kemungkinan penyebab terjadi sangat rendah & $\begin{array}{l}0,10 \text { per } 1000 \text { item } \\
0,50 \text { per } 1000 \text { item }\end{array}$ \\
\hline $4-6$ & $\begin{array}{l}\text { Kemungkinan terjadi bersifat moderat. Metode pencegahan } \\
\text { kadang memungkinkan penyebab itu terjadi }\end{array}$ & $\begin{array}{l}1,00 \text { per } 1000 \text { item } \\
2,00 \text { per } 1000 \text { item } \\
5,00 \text { per } 1000 \text { item }\end{array}$ \\
\hline $7-8$ & $\begin{array}{l}\text { Kemungkinan penyebab masih tinggi. Metode pencegahan } \\
\text { kurang efektif, penyebab masih berulang kembali. }\end{array}$ & $\begin{array}{l}10,00 \text { per } 1000 \text { item } \\
20,00 \text { per } 1000 \text { item }\end{array}$ \\
\hline $9-10$ & $\begin{array}{l}\text { Kemungkinan penyebab terjadi sangat tinggi. Metode } \\
\text { pencegahan tidak efektif penyebab selalu berulang kembali }\end{array}$ & $\begin{array}{r}50,00 \text { per } 1000 \text { item } \\
100,00 \text { per } 1000 \text { item }\end{array}$ \\
\hline
\end{tabular}

Sumber: Gasperz (2002)

Berdasarkan Tabel 9, hasil nilai RPN yang didapat melalui analisis FMEA, CTQ kemurnian gula pada proses evaporasi merupakan Risk Priority Number (RPN) dengan nilai tertinggi sebesar 105 RPN. Penambahan waktu tinggal gula proses di evaporator terjadi akibat tidak mencapai suhu aktual sehingga akan berdampak pada peningkatan nilai warna gula (ICUMSA Unit) melebihi standar. Widji T (2017) menjelaskan bahwa suhu evaporasi dapat diturunkan dengan menurunkan tekanan evaporator. Hal ini perlu dilakukan identifikasi adanya kemungkinan kebocoran sehingga udara bebas masuk ke dalam evaporator. Proses evaporasi yang baik akan menghasilkan kadar brix yang tepat sehingga akan membantu mempercepat pembentukan kristal pada saat proses pemasakan di vacum pan. 
Tabel 9. Failure mode and effect analysis (FMEA)

\begin{tabular}{|c|c|c|c|c|c|c|c|c|c|c|}
\hline \multirow{2}{*}{ No } & \multirow{2}{*}{ CTQ } & \multirow{2}{*}{ Deskripsi Proses } & \multirow{2}{*}{$\begin{array}{l}\text { Modus } \\
\text { Kegagalan }\end{array}$} & \multirow{2}{*}{$\begin{array}{l}\text { Efek Potensial } \\
\text { Modus } \\
\text { Kegagalan }\end{array}$} & \multirow{2}{*}{$\begin{array}{c}\text { Sebab } \\
\text { Potensial } \\
\text { Kegagalan }\end{array}$} & \multicolumn{3}{|c|}{ Nilai } & \multirow{2}{*}{ RPN } & \multirow{2}{*}{ Pengendalian } \\
\hline & & & & & & $\mathrm{S}$ & $\mathrm{O}$ & $\mathrm{D}$ & & \\
\hline 1 & $\begin{array}{l}\text { Kerapatan } \\
\text { kemasan }\end{array}$ & Proses Pengemasan & $\begin{array}{l}\text { Jahitan pada } \\
\text { kemasan } \\
\text { yang tidak } \\
\text { rapat }\end{array}$ & $\begin{array}{l}\text { Gula lebih peka } \\
\text { terhadap } \\
\text { lingkungan } \\
\text { ehingga rentan } \\
\text { terkontaminasi } \\
\text { mikroorganisme. }\end{array}$ & $\begin{array}{l}\text { Benang lepas } \\
\text { dan karung } \\
\text { sobek }\end{array}$ & 5 & 2 & 4 & 40 & $\begin{array}{l}\text { Pemeriksaan inner dan outer karung saat akan } \\
\text { digunakan, melakukan perbaikan pada conveyor } \\
\text { yang memiliki sisi ataupun bagian tajam, dan } \\
\text { pengawasan terhadap pemindahan produk } \\
\text { menggunakan forklift. }\end{array}$ \\
\hline 2 & $\begin{array}{l}\text { Daya tahan } \\
\text { produk }\end{array}$ & $\begin{array}{l}\text { Proses pengeringan } \\
\text { dan pendinginan }\end{array}$ & $\begin{array}{l}\text { Pengeringan } \\
\text { menjadi } \\
\text { lambat } \\
\text { sehingga } \\
\text { terjadi } \\
\text { penambahan } \\
\text { waktu } \\
\text { tinggal dan } \\
\text { pengurangan } \\
\text { kapasitas } \\
\text { material }\end{array}$ & $\begin{array}{l}\text { Gula terjadi } \\
\text { kontak langsung } \\
\text { dengan } \\
\text { lingkungan luar } \\
\text { saat dilakukan } \\
\text { maintenance } \\
\text { sehingga remelt } \\
\text { perlu dilakukan }\end{array}$ & $\begin{array}{l}\text { Terdapat } \\
\text { salah satu } \\
\text { kompartemen } \\
\text { yang belum } \\
\text { mencapai } \\
\text { suhu aktual }\end{array}$ & 7 & 4 & 3 & 84 & $\begin{array}{l}\text { Gula produk yang berada di salah satu } \\
\text { kompartemen yang mengalami penyimpangan } \\
\text { dilanjutkan ke kompartemen berikutnya } \\
\text { kemudian melakukan stop process pada gula } \\
\text { produk yang akan masuk selanjutnya ke tahap } \\
\text { ini untuk dilakukan pengosongan terlebih dahulu } \\
\text { sebelum dilakukan perbaikan. }\end{array}$ \\
\hline \multirow[t]{2}{*}{3} & $\begin{array}{l}\text { Kemurnian } \\
\text { Gula }\end{array}$ & $\begin{array}{l}\text { 1) Proses } \\
\text { Karbonatasi }\end{array}$ & $\begin{array}{l}\text { Tidak } \\
\text { mencapai } \\
\text { pH standar }\end{array}$ & $\begin{array}{l}\text { Kotoran pada } \\
\text { gula tidak dapat } \\
\text { diendapkan } \\
\text { dengan optimal }\end{array}$ & $\begin{array}{l}\text { Reaksi yang } \\
\text { berlangsung } \\
\text { saat di } \\
\text { reaction tank } \\
\quad \text { tidak } \\
\text { sempurna }\end{array}$ & 6 & 4 & 3 & 72 & $\begin{array}{l}\text { Penambahan ataupun pengurangan flow kapur. } \\
\text { Penyesuaian pH saat dikarbonator menggunakan } \\
\mathrm{CO}_{2 .} \text { Menambah lama waktu tinggal dengan } \\
\text { menambah level syrup. Kalibrasi pH meter } \\
\text { proses. }\end{array}$ \\
\hline & & 2) Proses Evaporasi & $\begin{array}{l}\text { Suhu saat } \\
\text { penguapan } \\
\text { tidak } \\
\text { mencapai } \\
\text { batas } \\
\text { standar } \\
\left(105^{\circ} \mathrm{C}\right)\end{array}$ & $\begin{array}{l}\text { Nilai warna (IU) } \\
\text { pada produk } \\
\text { akhir akan sulit } \\
\text { mencapai target }\end{array}$ & $\begin{array}{l}\text { Lama waktu } \\
\text { penguapan } \\
\text { bertambah } \\
\text { sehingga } \\
\text { peningkatan } \\
\text { terhadap nilai } \\
\text { warna (IU) }\end{array}$ & 7 & 5 & 3 & 105 & $\begin{array}{l}\text { Melakukan identifikasi temperature suhu apabila } \\
\text { terjadi terjadi ketidaksesuaian panel evaporator } \\
\text { dengan hasil analisis uji laboratorium }\end{array}$ \\
\hline
\end{tabular}




\section{KESIMPULAN DAN SARAN}

\section{Kesimpulan}

Rata-rata pencapaian persentase defect tiap bulan sebesar $0,07 \%$ belum mampu mencapai target yang ditentukan perusahaan sebesar $0,03 \%$. Tingkat sigma rata-rata per bulan $(5,04)$ dikategorikan ke dalam tingkatan kualitas rata-rata industri USA. Nilai kapabilitas $(\mathrm{Cp})=1,67$ artinya sangat baik sedangkan indeks kapabilitas $(\mathrm{Cpk})=1,198$ artinya kemampuan proses berkaitan CTQ tersebut perusahaan telah cukup mampu dan perlu upaya yang giat untuk peningkatan kualitas menuju target yang diinginkan. Faktor-faktor yang menyebabkan terjadinya penyimpangan pada produksi sebab-akibat adalah mesin dengan nilai Risk Priority Number (RPN $105)$.

\section{Saran}

Metode pengendalian kualitas statistik menggunakan six sigma dapat digunakan sebagai bahan pertimbangan dalam melakukan peningkatan kualitas melalui penentuan target toleransi jumlah dan penyebab defect. Evaluasi dilakukan tidak hanya saat terjadi penyimpangan tetapi evaluasi perlu dilakukan terhadap rekap data produksi dan jumlah ketidaksesuaian bulanan pada periode sebelumnya sehingga kemampuan proses ataupun tingkatan sigma yang diperoleh perusahaan dapat diketahui dan menjadi acuan untuk mencapai tingkat sigma 6 .

\section{DAFTAR PUSTAKA}

Arum, I.M.S. (2017). Analisis Kapabilitas Mutu di Pabrik Gula Tjoekir Jombang Periode Giling Tahun 2016. Unpublished undergraduate thesis, Institut Teknologi Sepuluh November, Surabaya.

Assauri, S. (2016). Manajemen Operasi Produksi Pencapaian Sasaran Organisasi Berkesinambungan ( ${ }^{\text {rd }}$ ed.). Jakarta: Rajawali Pers.

Basuki, B., \& Sari, V. K. (2020). Efektifitas dolomit dalam mempertahankan pH tanah Inceptisol Perkebunan Tebu Blimbing Djatiroto. Buletin Tanaman Tembakau, Serat \& Minyak Industri, 11(2), 58-64.

Bustami, B., \& Nurlela. (2007). Akuntansi Biaya Teori dan Aplikasi. Yogyakarta: Graha Ilmu.

Ekoanindiyo, F. A. (2014). Pengendalian Cacat Produk Dengan Pendekatan Six Sigma. Jurnal Ilmiah Dinamika Teknik, 8(1), 35-43.

Evans, J. R., \& Lindsay, W. M. (2007). An Introduction to Six Sigma and Process Improvesment. Jakarta: Salemba Empat.

Fajrin, A. El, Hartono, S., \& Waluyati, L. R. (2015). The demand for refined sugar in food and beverage and pharmaceutical industries (in Indonesia). Agro Ekonomi, 26(2), 150-158. https://doi.org/http://dx.doi.org/10.22146/agroekonomi.17267

Febrina, S. (2007). Penerapan Metode Six Sigma DMAIC untuk Perbaikan Kualitas Fisik Batang 
Rokok Merk Samudera Emas 16 pada Cigarette Maker Machine (Studi Kasus PT. Asia Marko). Unpublished undergraduate thesis, Universitas Sebelas Maret, Surakarta.

Findari, W. S., \& Nugroho, Y. A. (2019). Optimasi sistem antrian pada layanan kesehatan masyarakat menggunakan pendekatan simulasi. Jurnal Manajemen Industri dan Logistik, 3(1), 14-22.

Gasperz, V. (2002). Pedoman Implementasi Program Six Sigma Terintegrtitas dengan ISO, 9001:2000, MBNQA dan HACCP. Jakarta: PT Gramedia Pustaka Utama.

Gasperz, V. (2007). Lean Six Sigma. Jakarta: PT Gramedia Pustaka Utama.

Isnawati, S. F. (2009). Analisis Strategi Bersaing Gula Rafinasi pada PT Jawamanis Rafinasi. Unpublished undergraduate thesis, Institut Pertanian Bogor, Bogor.

Liquiddanu, E. (2007). Perbaikan Kualitas pada Proses Kiln Tegel Keramik Kode GE dengan Metode Six Sigma DMAIC (Studi Kasus PT . IKAD Tangerang ). Performa, 6(1), 1-13.

Park, S. H. (2003). Six Sigma for Quality and Productivity Promotion. Tokyo, Japan: Asian Productivity Organization.

Pusat Pengkajian Perdagangan Dalam Negeri. (2018). Analisis Perkembangan Harga Bahan Pangan Pokok di Pasar Domesrik dan Internasional. Kementerian Perdagangan Republik Indonesia.

Saputra, Y. H. (2020). Perspektif ketersediaan gula domestik dan swasembada gula nasional. Perspektif, 19(1), 63-78.

Sulistyowati, D. P., \& Anggarini, S. (2017). Pengendalian kualitas pengalengan jamur dengan metode six sigma di PT Y, Pasuruan, Jawa Timur. Jurnal Teknologi dan Manajemen Agroindustri, 6(1), 1-7.

Widji T, N. (2017). Perancangan vacum evaporator metode liquid ring vacum. Jurnal Teknik Kimia, 12(1), 24-27.

Wiyono, R.S. (2004). Penerapan Stastistical Process Control (SPC) pada Pengolahan Secara Basah Kopi Arabika. Unpublished undergraduate thesis, Universitas Jember, Jember. 